«Русский язык и литература в славянском мире: история и современность». Конференция в онлайн-формате

V.G. Moiseeva (Moscow, Russia)

\title{
"Russian Language and Literature in the Slavic World: History and Modernity". Online Conference
}

25 мая в Московском государственном университете имени М.В. Ломоносова при поддержке Общества русской словесности была проведена международная научно-практическая конференция «Русский язык и литература в славянском мире: история и современность». Подготовка к конференции началась в феврале 2020 г., когда мы еще не знали о пандемии, коронавирусе и не предполагали для мероприятия такого масштаба возможности использования онлайн-формата. К тому моменту, когда стало понятно, что в конце мая, в даты празднования Дней славянской письменности, проведение очной конференции невозможно, а было подано уже более 300 заявок, надо было принимать решение об отмене или изменении формата проведения этого научного форума. Было решено, что празднику славянской письменности, научному общению, встречам коллег-славистов 25 мая 2020 г. - быть, а для проведения решили использовать уже накопленный преподавателями Московского университета и их коллегами из вузов и школ России и других стран опыт дистанционного профессионального общения и преподавания. Все получилось. Доказательством того, что преподаватели высшей и средней школы за время вынужденного карантина и - в связи с этим - безальтернанивного выбора дистанционных форм обучения стали, как принято говорить, уверенными пользователями в области коммуникационных технологий, является тот факт, что количество участников конференции после предложения организаторами новой формы проведения не уменьшилась, а, наоборот, увеличилось, поскольку получили возможность подключения наши преподаватели, проживающие и работающие в других странах, в частности в США, Японии, Швеции и Швейцарии, а также иностранные коллеги из Индии, Китая, Словении, Чехии. Всего для участия в конференции было подано около 500 заявок. Работа конференции была организована в форме пленарного и секционных заседаний. 
Пленарное заседание открылось докладом ректора Московского университета академика Виктора Антоновича Садовничего, в котором была задана, условно говоря, пространственно-временна́я координата всей конференции, поскольку речь шла в том числе и об истории проведения Дней славистики в стенах Московского университета, и о судьбах ученых-филологов - участников Великой Отечественной войны, и о том, как сегодня Московский университет празднует 75-летие Победы.

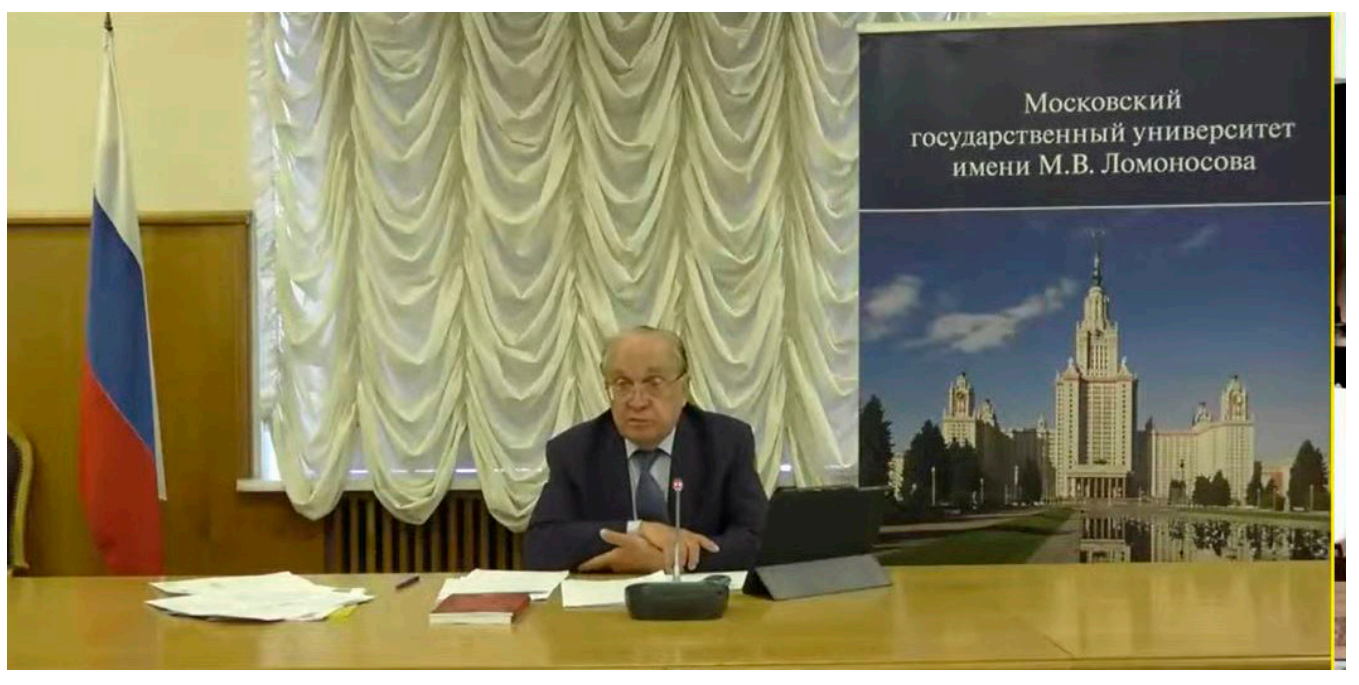

Пленарное заседание.

Доклад ректора Московского университета академика В.А. Садовничего

С приветственным словом к участникам конференции обратились министр просвещения Российской Федерации С.С. Кравцов, член Совета Федерации, член Бюро Общества русской словесности О.П. Ткач. Председатель Попечительского совета Российской академии образования, член Бюро Общества русской словесности О.Ю. Васильева выступила, по сути дела, с докладом, затрагивающим болевые точки преподавания русского языка и литературы в условиях современной школы. Трансляция пленарного заседания велась в прямом эфире на канале Youtube.com: к настоящему моменту зафиксировано 1357 просмотров - аудитория конференции значительно расширилась; надеемся, желающих посмотреть эти материалы будет еще больше ${ }^{1}$.

Для того чтобы все доклады, принятые программным комитетом, могли быть заслушаны с соблюдением временно́го регламента, несколько секций были разбиты на подсекции в соответствии с научными интересами участников. Знакомство с программой конференции свидетельствует о том, что тематика секционных заседаний была многоплановой, в докладах и обсуждениях речь шла о проблемах, актуальных для разных областей славистики: это и академическое изучение истории русского и других славянских языков, памятников славянской письменности, исследование русской и классической литературы в контексте славянских культурных связей, развитие и совершенствование с учетом новых информационно-коммуникационных возможностей методик преподавания русского языка как иностранного и методических подходов к преподаванию русского языка, изучению истории русской словесности в школе 2 .

\footnotetext{
${ }^{1}$ Приглашаем и наших читателей к ней присоединиться: https://www.youtube.com/embed/ftLprX69xRI ${ }^{2}$ Ознакомиться с подробным отчетом о работе секций можно на сайте конференции: https://rll2020. philol.msu.ru/.
} 


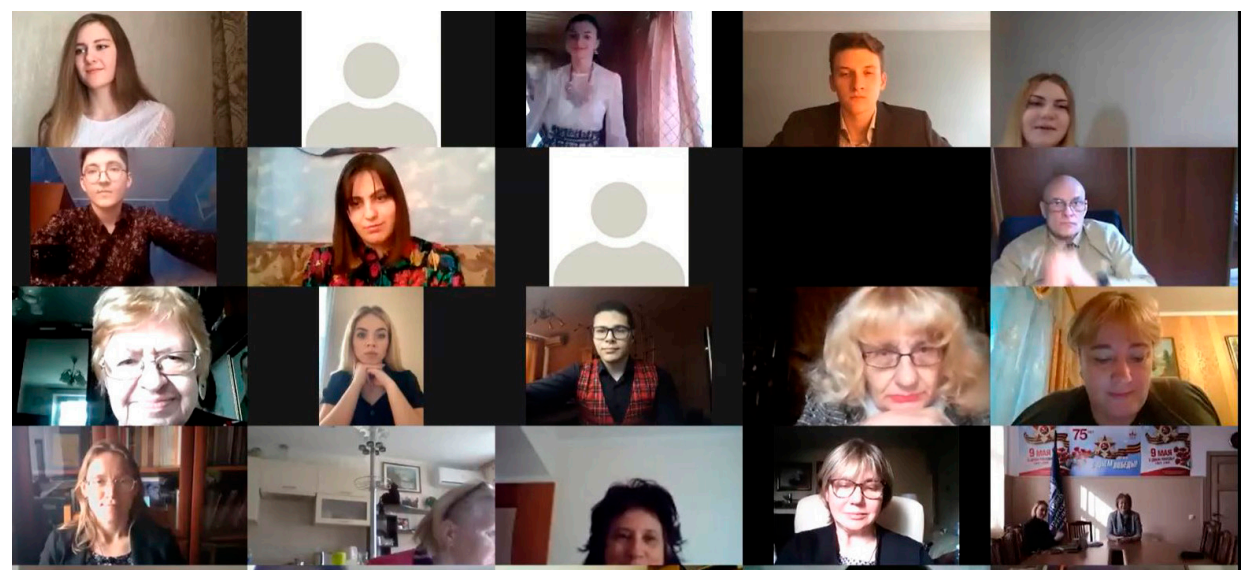

Закрытие конференциии

Хотелось бы поделиться некоторыми личными впечатлениями от нового формата проведения научных мероприятий: в некоторых случаях не хватало визуального контакта (поскольку не всегда была возможность подключить видеосвязь), но вместе с тем «кадровое пространство» каждого из участников, соблюдающих, естественно, режим самоизоляции в домашних условиях, делало визуальное пространство виртуальных аудиторий более разнообразным и, если можно так сказать, более демократичным, задавая дружеский тон общения.

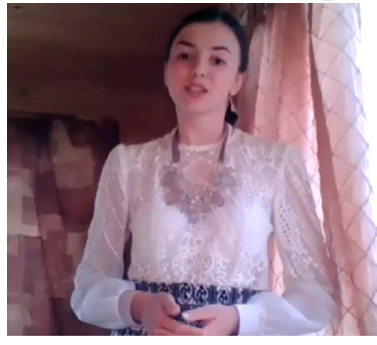

Кониерт

После заседания секций участники посетили концерт, организованный студентами и магистрантами Московского университета и ставший настоящим праздником славянской культуры, поскольку звучали песни и стихотворения на русском, польском, чешском, болгарском, украинском, сербском языках (https://www.youtube.com/watch?v=xrA6WdTa6k0).

На закрытии конференции исполняющий обязанности декана филологического факультета МГУ профессор Андрей Александрович Липгарт подвел итоги конференции, свидетельствующие о том, что научно-практическая конференция «Русский язык и литература в славянском мире: история и современность» стала площадкой для заинтересованного профессионального общения коллег из более чем 65 регионов Российской Федерации, стран ближнего и дальнего зарубежья.

Сведения об авторе:

Виктория Георгиевна Моисеева, канд. филол. наук научный сотрудник филологический факультет МГУ имени М.В. Ломоносова
Victoria Moiseeva,

$\mathrm{PhD}$

Research Associate

Philological Faculty

Lomonosov Moscow State University

moisvik44@gmail.com 